\title{
THE SEVERAL FACES OF SCHMORL'S NODE: PICTORIAL ESSAY
}

\author{
AS DIVERSAS FACES DO NÓDULO DE SCHMORL: ENSAIO PICTÓRICO
}

\author{
LAS DIVERSAS CARAS DEL NÓDULO DE SCHMORL: ENSAYO PICTÓRICO
}

Marcello Henrique Nogueira-Barbosa ${ }^{1}$, Michel Daoud Crema ${ }^{2,3}$, Carlos Fernando Pereira da Silva Herrero ${ }^{4}$, Wagner Pasqualini ${ }^{5}$, Helton Luiz Aparecido Defino ${ }^{4}$

\begin{abstract}
The aim of this review is to present the imaging features of Schmorl's node (SN) occurring in conjunction with several etiologies. The SN is a relatively common finding in diagnostic spinal imaging. This condition is usually asymptomatic and its etiology is not always clear. Any disorder that weakens the subchondral bone of the vertebral body may lead to endplate disruption and consequent intravertebral disc herniation. SN is a common finding among asymptomatic patients, but may possibly be accompanied by symptoms in cases of trauma, hemispherical spondylosclerosis, calcific discitis with intravertebral migration, inflammatory diseases and neoplasms. Even though SN is generally associated with benign diseases, its presence does not exclude the possibility of concomitant malignancy in the vertebral body. Radiologists and spine surgeons must be aware of uncommon conditions that might be associated with SNs, as well as related radiological findings, in order to avoid misdiagnosis.
\end{abstract}

Keywords: Spine; Intervertebral disc displacement; Radiography; Magnetic resonance imaging.

\section{RESUMO}

O objetivo desta revisão é apresentar as características de imagem do nódulo de Schmorl (NS) em conjunto com diversas etiologias. O NS é um achado relativamente comum nas imagens diagnósticas da coluna. Essa afecção geralmente é assintomática e sua etiologia nem sempre é clara. Qualquer doença que enfraqueça o osso subcondral do corpo vertebral pode levar à ruptura da placa terminal e, consequentemente, à hérnia intrassomática do disco intervertebral. O NS é comum em pacientes assintomáticos, mas pode eventualmente ser acompanhado de sintomas em casos de trauma, espondiloesclerose hemisférica, discite calcificada com migração intravertebral, doenças inflamatórias e neoplasias. Embora o NS seja, em geral, associado a doenças benignas, sua presença não exclui a possibilidade de doença maligna concomitante no corpo vertebral. Radiologistas e cirurgiões de coluna devem estar cientes das apresentações menos comuns do NS e dos achados radiológicos relacionados, a fim de evitar erros de diagnóstico.

Descritores: Coluna vertebral; Deslocamento do disco intervertebral; Radiografia; Imagem por ressonância magnética.

\section{RESUMEN}

El objetivo de esta revisión es presentar las características de imagen del nódulo de Schmorl (NS) que ocurren en conjunto con varias etiologías. EI NS es un hallazgo relativamente común en imágenes diagnósticas de la columna vertebral. Esta condición suele ser asintomática y su etiología no siempre es clara. Cualquier enfermedad que debilita el hueso subcondral del cuerpo vertebral puede conducir a la ruptura de la placa terminal y la consiguiente hernia de disco intervertebral. El NS es un hallazgo frecuente en pacientes asintomáticos, pero, posiblemente, puede estar acompañada de síntomas en casos de trauma, espondiloesclerosis hemisférica, discitis calcificada con migración intravertebral, enfermedades inflamatorias y neoplasias. A pesar de que el NS se asocia generalmente con enfermedades benignas, su presencia no excluye la posibilidad de malignidad concomitante en el cuerpo vertebral. Los radiólogos y cirujanos de columna deben ser conscientes de las presentaciones menos comunes del NS, así como los hallazgos radiológicos relacionados, a fin de evitar un diagnóstico equivocado.

Descriptores: Columna vertebral; Desplazamiento del disco intervertebral; Radiografía; Imagen por Resonancia Magnética.

\section{INTRODUCTION}

Schmorl's nodes (SN) represent intervertebral disk tissue that has been displaced through the cartilaginous endplate into the vertebral body. These cartilaginous nodes are most frequently observed in the lumbar and lower thoracic spine, a common finding in the general population. ${ }^{1}$

SNs may be difficult to detect on conventional radiographs when they are small. However, when an SN is depicted, its radiographic and tomographic appearance is usually typical, (Figure 1) with a small, focal, rounded form, and radiolucency in the subchondral bone of the vertebral body, broad-based at the vertebral plateau and with varying degrees of adjacent reactive sclerosis. ${ }^{2}$ Vacuum phenomena in the intervertebral disc space or within the SN, may also be seen. (Figures 2 and 3 )

Weakening of the cartilaginous endplate and subchondral bone, believed to be the cause of SNs, might be related to pathologic conditions such as Scheuermann's disease, metabolic diseases and neoplastic disorders of spine. ${ }^{2}$ A previous study with histological evaluation suggested that SNs may be the result of ischemic necrosis beneath the cartilaginous endplate, and that disc herniation into the vertebral body is a secondary phenomenon. ${ }^{3}$ The occurrence of SNs has also been linked to trauma and vertebral fractures; 4,5 these are often described as acute SNs, especially in symptomatic cases, which have been associated with acute trauma or microtrauma. ${ }^{5-8}$ Acute SNs have recently been documented as a rare complication

1. Universidade de São Paulo, Faculdade de Medicina de Ribeirão Preto, Radiology Division de, Ribeirão Preto, SP, Brazil.

2. Hospital do Coração e Teleimagem, Department of Radiology, São Paulo, SP, Brazil.

3. Quantitative Imaging Center, Department of Radiology, Boston University School of Medicine, Boston, MA, USA.

4. Universidade de São Paulo, Faculdade de Medicina de Ribeirão Preto, Department of Biomechanics, Medicinea and Rehabilitation of the Locomotor Apparatus, Ribeirão Preto, SP, Brazil.

5. Universidade Estadual de Campinas, Faculdade de Ciências Médicas, Department of Orthopedic Surgery andTraumatology, Campinas, SP, Brazil.

Correspondence: Radiology Division Faculty of Medicine of Ribeirao Preto - University of Sao Paulo - USP

Av. Bandeirantes, 3900. Ribeirao Preto, São Paulo 14049-090. marcello@fmrp.usp.br 


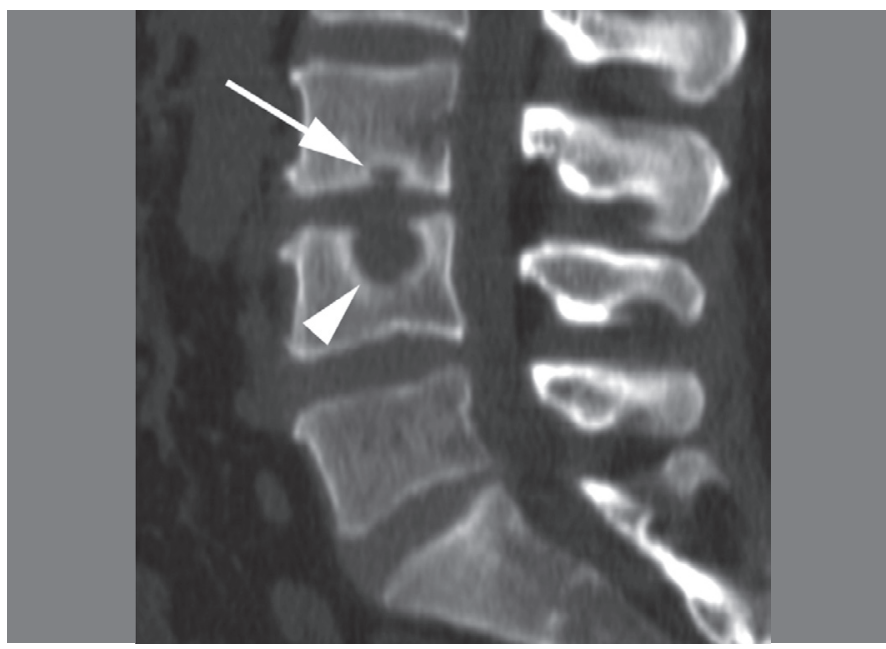

Figure 1. 56-year-old woman with low back pain. Sagittal CT reformat showed typical SN features, as observed for the small SN at the inferior endplate of the L3 vertebral body (arrow): the vertebral nodule was broad-based at the endplate, with well-defined contours and thin marginal sclerosis. A large and less typical SN (arrowhead) is observed at the superior endplate of L4.

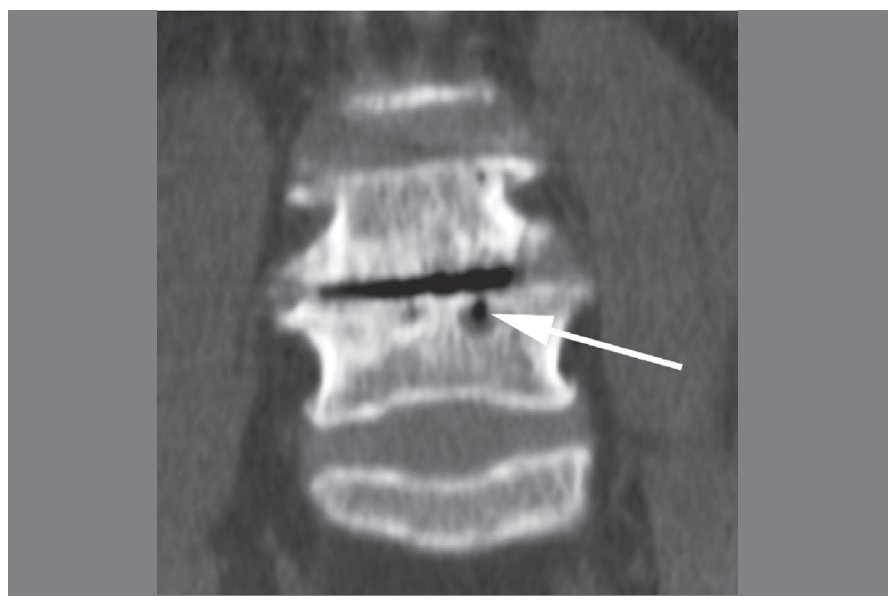

Figure 2. 63-year-old woman with low back pain. Advanced disk degeneration with vacuum phenomena associated with gas collection (arrow) inside the SN.
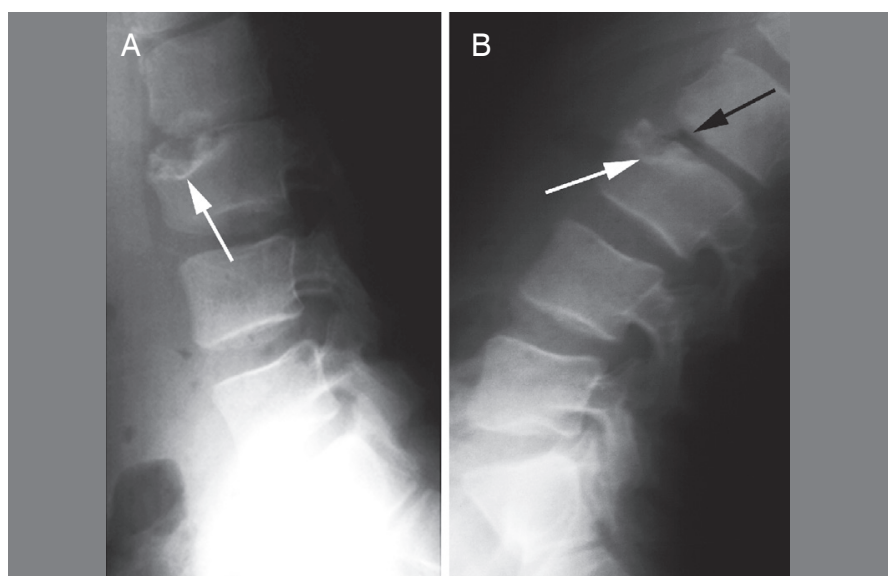

Figure 3. 14-year-old boy with back pain and idiopathic SN. There was no clear documented history of trauma. (A) Lateral view X-ray showed a focal lesion with marginal bone sclerosis at the discovertebral junction in the anterosuperior aspect of the L3 vertebral body (arrow). (B), Lateral view X-ray with orthostatic extension view depicts vacuum phenomena in the intervertebral disc, extending into the SN. Clinical and laboratorial follow-up and percutaneous biopsy ruled out infection and neoplasm. of discography. ${ }^{9}$ In clinical practice, non-acute SNs are commonly depicted as incidental findings in imaging assessment, and are usually considered idiopathic.

In magnetic resonance imaging (MRI), enhancement of SNs may be observed after intravenous gadolinium administration in patients with and without back pain. ${ }^{10}$ This enhancement was shown to be present in larger SNs, which are believed to be more frequently associated with surrounding bone marrow edema in patients with back pain, as compared to asymptomatic patients. ${ }^{10}$

The purpose of this review is to present imaging patterns of symptomatic SN caused by different etiologies, including findings derived from radiographs, computed tomography (CT), and magnetic resonance imaging $(\mathrm{MRI})$.

\section{TRAUMATIC SNS}

SNs may be the result of acute trauma, as commonly observed in subjects with back pain. ${ }^{5-7}$ Another possible presentation of traumatic SNs is a large vertebral body cystic lesion associated with focal endplate disruption. ${ }^{8}$ (Figure 4 ) This type of presentation may potentially lead to a misdiagnosis of more aggressive pathologies, such as infection or neoplasm. Zones of weakness in the endplate cartilage may predispose to SNs following subclinical trauma. ${ }^{5}$ In such cases, the trauma episode may not be well documented, and the radiological changes at the discovertebral junction may be atypical, and easily misinterpreted as evidence of other conditions. Acute and subacute SNs associated with trauma may exhibit a pattern of surrounding bone marrow edema in MRI. ${ }^{6}$

\section{Hemispherical spondylosclerosis or discogenic bone sclerosis with SNs}

Hemispherical spondylosclerosis has initially been described on conventional radiographs as a dome-shaped sclerosis of the vertebral body, being broad-based at the discovertebral junction. This term was first used by Dihlmann, and degenerative disk disease is considered the most common cause of this condition, though it may also occur in conjunction with infection or metastasis. ${ }^{11}$

Before the term hemispherical spondylosclerosis was used, a series of cases thought to be related to subclinical trauma showed a similar pattern of broad-based bone sclerosis in about half of all cases. ${ }^{5}$ Histopathologic evaluation showed only reactive granulation tissue and microscopic bone fragments. ${ }^{5} \mathrm{CT}$ with multiplanar reconstructions may be useful to identify small SNs associated with reactive subchondral broad-based bone sclerosis. (Figures 5 and 6)

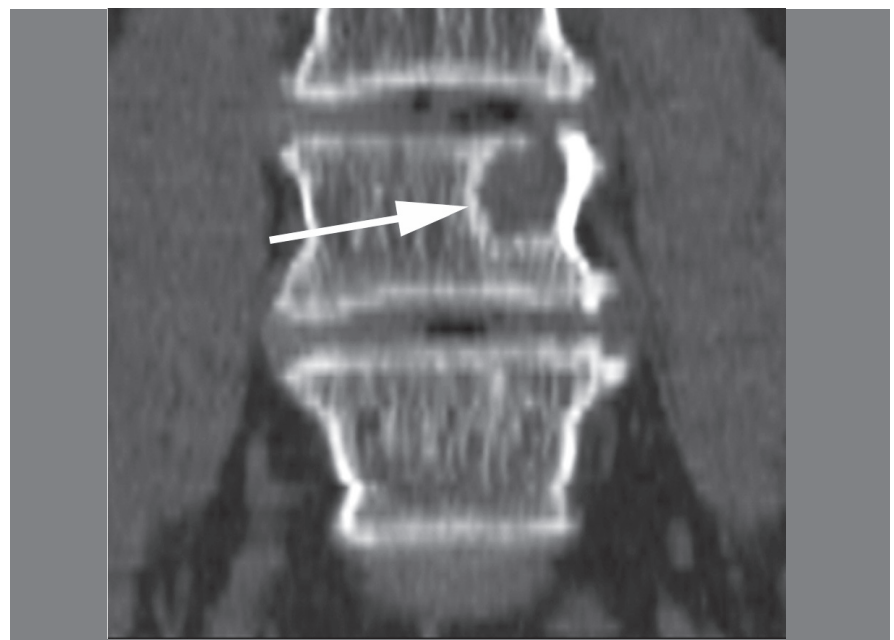

Figure 4. 73-year-old man with lumbar pain and a focal lesion at the L4 vertebral body (arrow) came to the University Hospital to rule out malignancy. There was an episode of trauma, a fall from a horse, about six months previously. Percutaneous biopsy showed that disc cartilaginous material had herniated into the vertebral bone and marginal reactive bone. 


\section{Calcific discitis with intravertebral migration}

Calcification of the intervertebral disk represents a common incidental finding on radiographic examination. Painful disc calcification has been more often reported in the pediatric population, and symptoms may include torticollis, fever, leukocytosis and elevated erythrocyte sedimentation rate. ${ }^{12,13}$ The cause of calcific discitis in childhood is not known, but the prognosis is excellent, as the pain resolves within a few days or weeks with conservative treatment, in most cases. Acute calcific discitis may, in rare cases, involve the adult population. ${ }^{14}$ (Figure 7 ) On radiographs, symptomatic calcifications typically involve the nucleus pulposus and the cervical spine. Such disk calcifications may migrate into the vertebral bodies following an SN, often associated with adjacent reactive bone sclerosis. Other sites of migration include the intervertebral foramina, the spinal canal, and the adjacent soft tissues. ${ }^{12}$ The MRI features of calcific discitis were recently described, and include disc swelling and bulging in the early stages, which may be seen before calcifications are visible on plain films. ${ }^{13}$ Changes in signal intensity may also occur within the adjacent vertebral bodies.

\section{Vertebral metastasis with SNs}

Any disorder that weakens the subchondral bone of the vertebral body may lead to endplate disruption and intravertebral disc herniation. The association between SN and vertebral metastasis has been described in cadavers with prostatic cancer. ${ }^{15}$ Vertebral metastases from other primary neoplasms may also be seen in conjunction with SNs. (Figures 8 and 9)

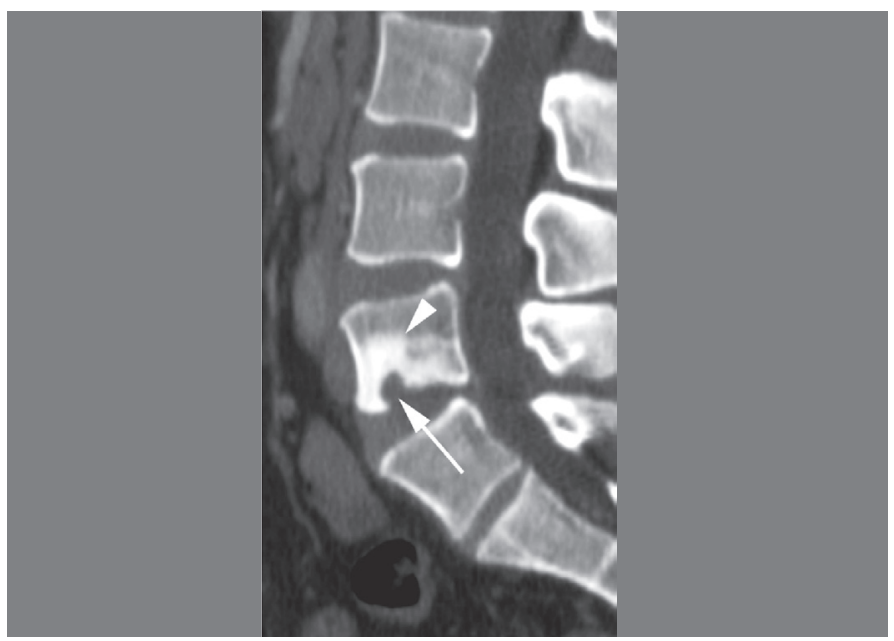

Figure 5. 36-year-old woman with chronic low back pain. SN associated to hemispherical reactive bone sclerosis. Sagittal CT reformat showed a SN at the L4 inferior endplate (arrow) associated with important adjacent reactive bone sclerosis (arrowhead). Biopsy and clinical follow-up ruled out infection and neoplasm.

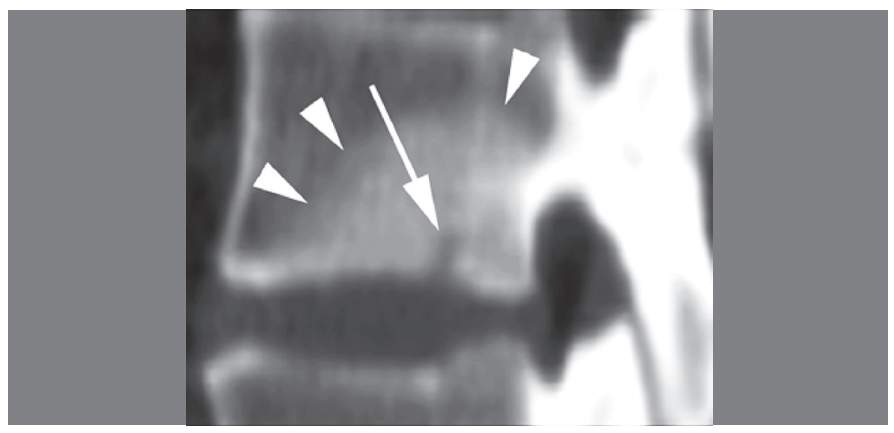

Figure 6. 40-year-old man with chronic back pain. SN associated with hemispherical reactive bone sclerosis. The sagittal CT reformat showed a small SN (arrow) associated with a dome-shaped bone sclerosis at the anteroinferior corner of the vertebral body (arrowheads). Clinical follow-up and laboratorial examinations ruled out infection and neoplasm.
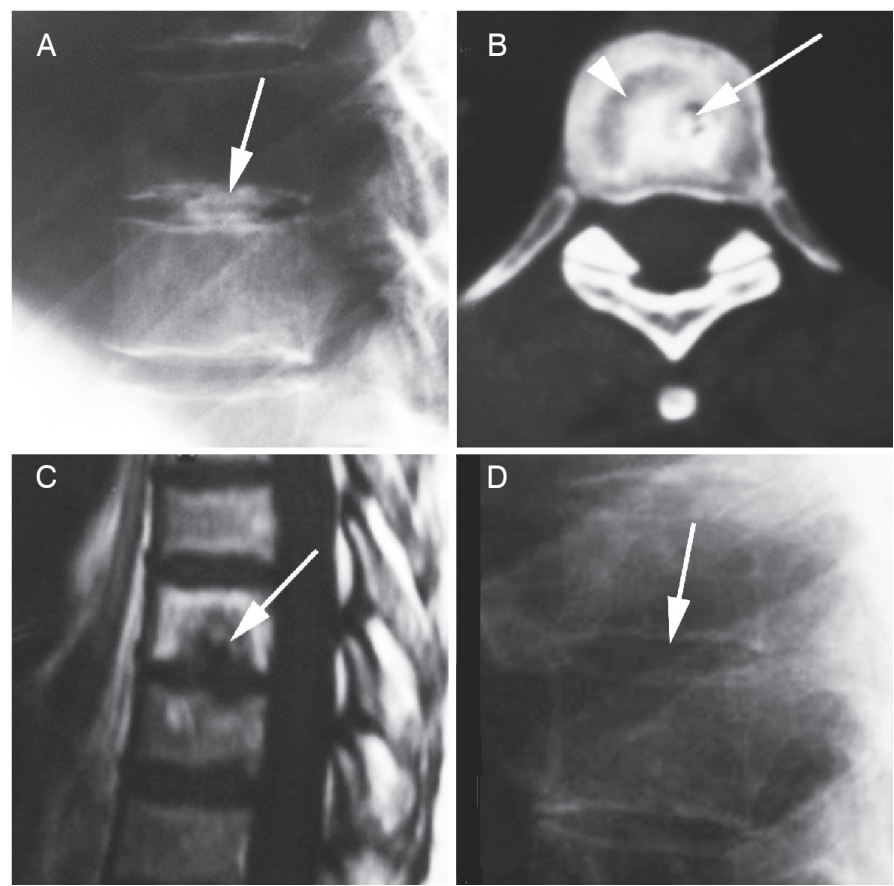

Figure 7. 48-year-old woman with back pain. Calcific discitis evolved with intravertebral migration of the calcification. (A) Lateral view X-ray showed a T7-8 level intervertebral disc calcification (arrow). (B) Axial CT showed a SN with central calcification (arrow), with surrounding bone sclerosis (arrowhead). (C) Sagittal T1-weighted MRI also showed an SN with interior low signal intensity (arrow) corresponding to the calcification migration seen on CT, as well as chronic reactive subchondral bone changes with predominant bone marrow fat substitution. (D) Lateral view $\mathrm{X}$-ray performed five years later showed complete resolution of calcification.

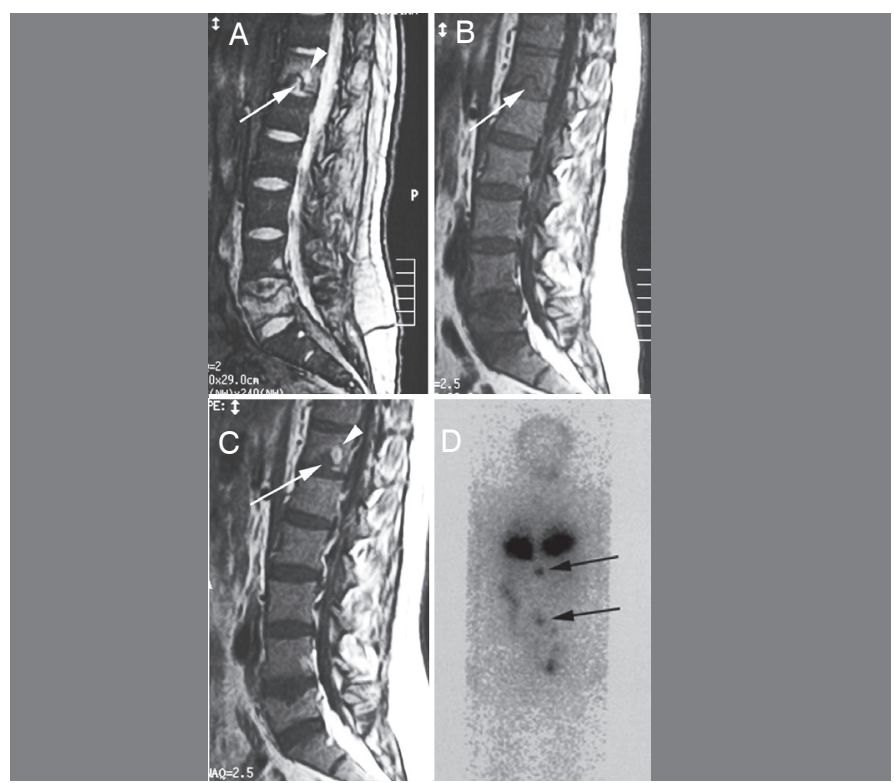

Figure 8. 28-year-old man with back pain and vertebral metastasis from thyroid carcinoma associated with SNs. (A) Sagittal T2-weighted MRI revealed an SN at the inferior endplate of T12 (arrow) with adjacent high, non-specific bone marrow signal abnormality (arrowhead). A pathologic fracture of $L 5$ was also seen, with abnormal bone marrow signal and vertebral body collapse. (B) Sagittal T1-weighted MRI also depicted the SN at the inferior endplate of T12 (arrow). (C) Sagittal T1-weighted MRI after intravenous gadolinium administration revealed pathologic and nodular enhancement (arrowhead) adjacent to the SN (arrow). (D) Posterior projection on iodine-131 scintigraphy showed uptake at T12 and L5 (arrows), which confirmed the diagnosis of thyroid carcinoma vertebral metastasis. 


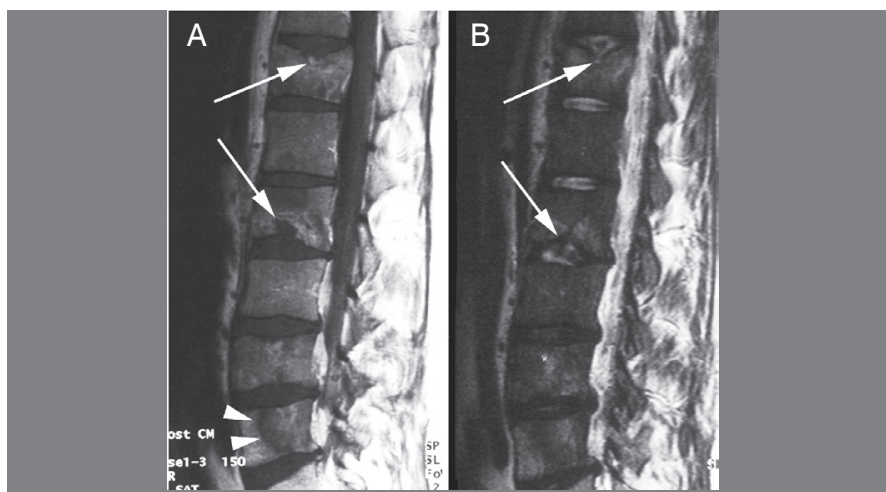

Figure 9. 35-year-old man with back pain and biopsy-proven thymus carcinoma vertebral metastasis. (A) Sagittal T1-weighted MRI after intravenous gadolinium administration showed pathologic bone marrow enhancement adjacent to SNs at the superior T12 endplate and the inferior L2 endplate (arrows). A nodular metastasis is also observed at L5 (arrowheads). (B) Sagittal T2-weighted MRI revealed pathologic fractures associated with SNs at the superior T12 endplate and the inferior L2 endplate (arrows)
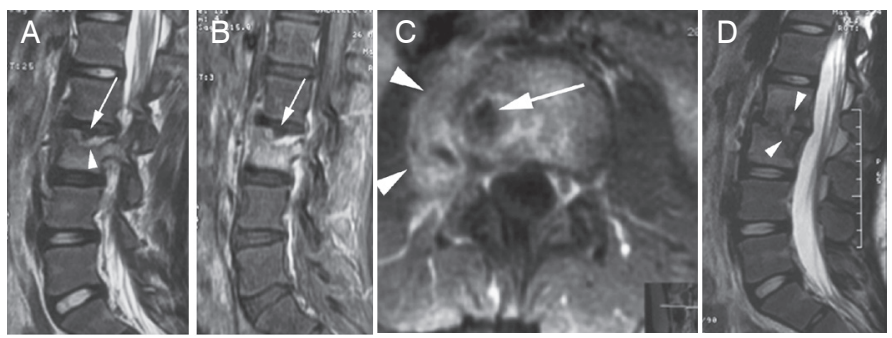

Figure 10. 11-year-old girl with low back pain and spine infection. Percutaneous biopsy with a positive culture proved Staphylococcus aureus spondylodiscitis. (A to C): initial MRI. (D): 6-month follow-up MRI. A) Sagittal T2-weighted MRI depicted a SN (arrow) at the superior endplate of the L3 vertebra and adjacent bone marrow edema-like changes (arrowhead). Fat-suppressed sagittal, B) and axial, C) T1-weighted MRI after intravenous gadolinium administration also showed the SN (arrow), with diffuse marrow enhancement in the L3 vertebral body. Note the paravertebral inflammatory collection, consistent with an abscess (arrowheads, C),D) T2-weighted sagittal MRI obtained 6 months later showed destruction of the disc space associated with SNs in both adjacent plates (arrowheads).

\section{Inflammatory/infectious diseases with SNs}

Weakening of the endplate and SNs may, in sporadic cases, be related to infectious spondylodiscitis (Figure 10) or to other inflammatory spine diseases, such as ankylosing spondilytis. ${ }^{16}$ (Figure 11)

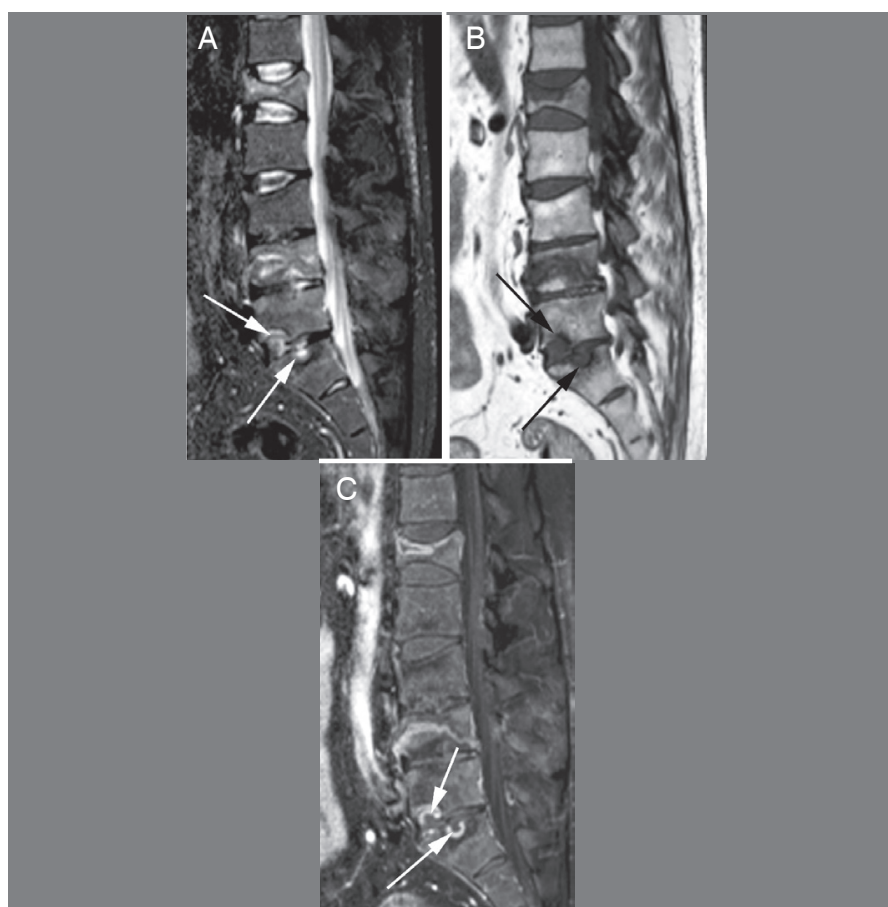

Figure 11. 39-year-old man with ankylosing spondylitis (AS) and low back pain Biopsy was necessary to rule out infection since destructive and inflammatory changes were observed. Changes were progressive in L5-S1 discovertebral transitions; the biopsy addressed this region. Sagittal T2-weighted fat-suppressed (A) and T1-weighted (B) MRI with arrows pointing at a small SN at the superior endplate of S1 and a larger SN at the L5 endplate. (C) Sagittal T1-weighted fat-suppressed MRI after intravenous administration of gadolinium showed inflammatory peripheral enhancement at the SNs (arrows)

\section{FINAL CONSIDERATIONS}

SNs represent a relatively common finding in spinal imaging. This condition is usually asymptomatic, and its etiology remains unclear. Even though SNs are almost always related to benign pathology, its presence does not rule out the possibility of concomitant malignant disease in the vertebral body. Radiologists and spine surgeons must be aware of uncommon conditions that might be associated with $\mathrm{SNs}$, as well as related radiological findings, in order to avoid misdiagnosis.

All authors declare no potential conflict of interest concerning this article.

\section{REFERENCES}

1. Dar G, Peleg S, Masharawi Y, Steinberg N, May H, Hershkovitz I. Demographical aspects of Schmorl nodes: a skeletal study. Spine (Phila Pa 1976). 2009;34(9):E312-5

2. Resnick D, Niwayama G. Intravertebral disk herniations: cartilaginous (Schmorl's) nodes. Radiology. 1978;126(1):57-65

3. Peng B, Wu W, Hou S, Shang W, Wang X, Yang Y. The pathogenesis of Schmorl's nodes. J Bone Joint Surg Br. 2003:85(6):879-82.

4. Peters CA, Vande Berg BC, Galand C, Lecouvet FE, Malghem J. Fracture-associated and idiopathic subchondral vertebral lesions: a magnetic resonance study in autopsy specimens with histologic correlation. Skeletal Radiol. 2009;38(3):245-53.

5. Martel W, Seeger JF, Wicks JD, Washburn RL. Traumatic lesions of the discovertebral junction in the lumbar spine. AJR Am J Roentgenol. 1976:127(3):457-64.

6. Walters G, Coumas JM, Akins CM, Ragland RL. Magnetic resonance imaging of acute symptomatic Schmorl's node formation. Pediatr Emerg Care. 1991;7(5):294-6.

7. Wagner AL, Murtagh FR, Arrington JA, Stallworth D. Relationship of Schmorl's nodes to vertebral body endplate fractures and acute endplate disk extrusions. AJNR Am J Neuroradiol. 2000:21(2):276-81.

8. Hauger O, Cotten A, Chateil JF, Borg O, Moinard M, Diard F. Giant cystic Schmorl's nodes: imaging findings in six patients. AJR Am J Roentgenol. 2001;176(4):969-72.
9. Pilet B, Salgado R, Van Havenbergh T, Parizel PM. Development of acute schmorl nodes after discography. J Comput Assist Tomogr. 2009:33(4):597-600.

10. Stäbler A, Bellan M, Weiss M, Gärtner C, Brossmann J, Reiser MF. MR imaging of enhancing intraosseous disk herniation (Schmorl's nodes). AJR Am J Roentgenol. 1997;168(4):933-8.

11. Dihlmann W. Hemispherical spondylosclerosis-a polyetiologic syndrome. Skeletal Radiol. 1981:7(2):99-106.

12. Sonnabend DH, Taylor TK, Chapman GK. Intervertebral disc calcification syndromes in children. J Bone Joint Surg Br. 1982;64(1):25-31.

13. Swischuk LE, Jubang M, Jadhav SP. Calcific discitis in children: vertebral body involvement (possible insight into etiology). Emerg Radiol. 2008:15(6):427-30.

14. Nogueira-Barbosa MH, da Silva Herrero CF PasqualiniW, Defino HL Calcific discitis in an adult patient with intravertebral migration and spontaneous remission. Skeletal Radiol. 2013;42(8):1161-4

15. Resnick D, Niwayama G. Intervertebral disc abnormalities associated with vertebral metastasis: observations in patients and cadavers with prostatic cancer. Invest Radiol. 1978:13(3):182-90.

16. Cawley MI, Chalmers TM, Kellgren JH, Ball J. Destructive lesions of vertebral bodies in ankylosing spondylitis. Ann Rheum Dis. 1972;31(5):345-58. 